\title{
Das fontes ao anseio de justiça: Contemplação poética e mística em Sophia de Mello Breyner Andresen
}

\author{
Ceci Maria Costa Baptista Mariani
}

Pontifícia Universidade Católica de Campinas

\section{Resumo}

Segundo Karl Rahner (1964), o cristão, sendo um ouvinte da Palavra de Deus encarnada na história, deve estar capacitado, exercitado e agraciado para ouvir a palavra poética que é a palavra mediante a qual o mistério se torna presente. A poesia é parte essencial do humano porque evoca o Mistério Inefável presente no humano e no mundo. Assumindo como justificativa a palavra do teólogo, colocamo-nos, a partir da teologia, à escuta de Sophia de Mello Breyner Andresen, com o objetivo de explicitar em seus poemas a relação entre mística e poesia. A proposta deste artigo é apontar os elementos místicos presentes na poesia de Sophia de Mello Breyner Andresen (1919-2004), tendo como referências os teólogos K. Rahner, J. Moltmann, E. Schillebeeckx e J. B. Metz. Mais especificamente sobre o fenômeno místico e suas características essenciais, recorremos à análise fenomenológica de Juan Martin Velasco e à abordagem histórica de Bernard McGinn. No que diz respeito ao diálogo com a crítica literária, contamos principalmente com o estudo realizado por Carlos Ceia. Na escuta dos poemas de Sophia, tomando o cuidado de não fazer uma identificação ingênua entre o discurso literário e a teologia da revelação, como recomenda Kuschel, procuramos reconhecer a presença de elementos místicos, especialmente relacionados com o estilo despojado (gosto pela simplicidade) e a experiência de Deus como Mistério Santo na contemplação da natureza, elementos que se desdobram na manifestação de um anseio de justiça, possibilitando aproximar a obra da poeta de uma "Mística de Olhos Abertos" (Metz).

Palavras-chave: Mística; poesia; Sophia Andresen; contemplação; compromisso social.

\section{From the sources to the yearning for justice Poetic contemplation and mystics in Sophia de Mello Breyner Andresen}

\footnotetext{
Abstract

According to Karl Rahner (1964), the Christian, as a listener to the Word of God incarnated in history, must be trained, exercised and gifted in order to listen to the poetic word, which mediates the mystery that becomes present. Poetry is an essential part of
} 
the human experience because it evokes the Ineffable Mystery present in humanity and in the world. Assuming Rahner's words as justificatory, we read and analise Sophia de Mello Breyner Andresen's work from the perpective of theology, aiming to uncover the relationship between mystics and poetry. The theologian's task, according to Rahner's reflection, is to face poetry without reducing it to a catechesis lesson, to explore what is inside of it, to point out an aspect from the relationship with God that reveals itself in creation, while still being a Holy Mystery. The purpose of this article is to point out the mystical elements present in the poetry of Sophia de Mello Breyner Andresen (1919-2004), having the theologians K. Rahner, J. Moltmann, E. Schillebeeckx and J. B. Metz as references. More specifically on the mystical phenomenon and its essential characteristics, we Make use of the phenomenological analysis of Juan Martin Velasco and the historical approach of Bernard McGinn. Regarding the relationship with literary criticism, we rely mainly on Carlos Ceia's studies. Approaching Sophia's poems, we were attentive not to make a naive identification between literary discourse and the theology of Revelation. As Kuschel recommends, we seek to recognize the presence of mystical elements, especially related to her unpretentious style (a taste for simplicity) and the experience of God as a Holy Mystery in the contemplation of nature. Those are elements that unfold along with the manifestation of a yearning for justice, making it possible to bring the poet's work closer to a "Mystique with Open Eyes" (Metz)

Keywords: Mystics; poetry; Sophia Andresen; contemplation; social commitment.

\section{De las fuentes al deseo de justicia: Contemplación poética y mística en Sophia de Mello Breyner Andresen}

\section{Resumen}

Según Karl Rahner (1964), el cristiano, al ser oyente de la Palabra de Dios encarnada en la historia, debe estar entrenado, ejercitado y dotado para escuchar la palabra poética que es la palabra a través de la cual se hace presente el misterio. La poesía es parte esencial de lo humano porque evoca el Misterio Inefable presente en lo humano y en el mundo. Asumiendo la palabra del teólogo como justificación, partimos, desde la teología, de escuchar a Sophia de Mello Breyner Andresen, con el objetivo de explicar en sus poemas la relación entre misticismo y poesía. El propósito de este artículo es señalar los elementos místicos presentes en la poesía de Sophia de Mello Breyner Andresen (1919-2004), teniendo como referencia a los teólogos K. Rahner, J. Moltmann, E. Schillebeeckx y J. B. Metz. Más específicamente sobre el fenómeno místico y sus características esenciales, utilizamos el análisis fenomenológico de Juan Martín Velasco y el enfoque histórico de Bernard McGinn. En cuanto al diálogo con la crítica literaria, nos apoyamos principalmente en el estudio de Carlos Ceia. Al escuchar los poemas de Sophia, cuidando de no hacer una identificación ingenua entre el discurso literario y la teología de la revelación, como recomienda Kuschel, intentamos reconocer la presencia de elementos místicos, especialmente relacionados con el estilo despojado (gusto por la sencillez) y la experiencia de Dios como Santo Misterio en la contemplación de la naturaleza, elementos que se despliegan en la manifestación de un anhelo de justicia, posibilitando acercar la obra del poeta a una "Mística de los ojos abiertos" (Metz).

Palabras clave: Mística; poesía; Sophia Andresen; contemplación; compromiso social. 


\section{Introdução: a escuta da poesia como tarefa da teologia}

Em seus Escritos de Teologia (1964), discorrendo sobre a vida cristã, Rahner, grande teólogo, afirma, introduzindo um tópico sobre a palavra poética e o cristão, que só um poeta poderia falar sobre poesia. Todavia, ele pondera, o poeta fala aos não poetas, portanto, os não poetas devem saber o que é a poesia. Ademais, ele acrescenta, o crente, sendo guiado pelo Espírito, pode julgar tudo. Por isso, ele conclui, enquanto reflexão do crente, a teologia não pode estar alheia à poesia: "pois em todos os campos do mundo, por diversos que sejam, deve amadurecer a semente única do único Deus" (RAHNER, 1964, p. 453; tradução nossa) ${ }^{1}$.

Para o teólogo, o cristão, sendo um ouvinte da Palavra de Deus encarnada na história, deve estar capacitado, exercitado e agraciado para ouvir a palavra poética que é a palavra mediante a qual o mistério se torna presente.

Mas visto que a palavra humana existe como corpo da Palavra permanente infinita de Deus e uma vez que essa Palavra é ouvida por meio de sua corporeidade permanente, há um nimbo de esplendor e uma promessa oculta em toda palavra. Em cada uma pode ocorrer a encarnação da graça com a Palavra mesma, permanente de Deus e, nela, com o próprio Deus. Ouvir bem a palavra supõe sempre escutar atentamente indo ao fundo, à mais íntima profundidade de cada palavra, esperando que talvez precisamente aí, ao afirmar o homem e o seu mundo, de repente ela se transforme em palavra de amor infinito (RAHNER, 1964, p. 460; tradução nossa)2.

O dizer e o ouvir poéticos são partes essenciais do humano. A palavra poética não fala sobre algo, mas, ao dizer, funda o que evoca. Ao dizer o particular, fala poeticamente do todo. Segundo o olhar de Rahner, evoca o mistério eterno inefável presente no humano e no mundo. No entanto, a grande poesia só existe, ele adverte, quando o humano enfrenta a si mesmo, encarando tudo o que o constitui na radicalidade de sua existência mundana,

\footnotetext{
1 "Pues em todos los campos del mundo, por muy diversos que sean, deve madurar la siembra única del único Dios".

2 "Pero desde que existe la palavra humana como cuerpo de la Palabra permanente infinita de Dios y desde que esa Palabra es oída em médio de su permanente corporeidade, hay un nimbo de esplendor y una promessa oculta sobre toda palavra. Em cada una puede acaecer la encarnación del agraciamiento con la Palabra misma, permanente de Dios y, en ella, com Dios mismo. Oír bien la palavra supone siempre escuchar atentamente hacia lo fondo, hacia la más íntima profundidad de cada palavra, en la espera de que quizás precisamente ahí, al afirmar al hombre y su mundo, llegue a ser de pronto la palavra del amor infinito".
} 
incluindo culpa, perversão, ódio de si mesmo, soberba satânica; pois é nesse enfrentamento, ele pondera, que se encontra o "bendito risco" de tropeçar em Deus. A grande poesia é, porém, misteriosa e obscura. Deixa sem resposta a questão de estar se referindo ao mistério da graça ou da perdição. Não é um discurso moral. Fala do concreto, deixando que o juízo de Deus, que desvela o mistério nas coisas, faça-se presente em forma de mistério (cf. RAHNER, 1964, p. 464).

A poesia autêntica, diferente da literatura que não é mais que distração no mercado do cotidiano, conquanto trate da culpa e do desamparo, do trágico e do tormento infernal que recai sobre o humano, inclui, é certo, o sereno e o celeste, o espontâneo e o gozosamente ingênuo (RAHNER, 1964, p.465), pois, conclui ele com o otimismo salvífico próprio de sua antropologia teológica, a liberdade bem-aventurada do céu, mais que o inferno, é na realidade o que há de mais sério na história da revelação de Deus (RAHNER, 1964 , p. 146). O cristão, portanto, ele afirma, e a teologia enquanto reflexão do crente, podemos inferir, têm uma responsabilidade ante a poesia e sua inteligência, pois a palavra da poesia prepara os ouvidos para a percepção do mistério que implica a salvação.

Segundo Clodovis Boff (2015, p. 81-85), as asserções relativas à revelação, objeto da teologia, só podem ser fruto de argumentos derivados da racionalidade "de conveniência", ou "persuasiva". As questões relativas à natureza interna das verdades de fé podem ser, mas nem sempre são objetos de argumentos necessários, apodíticos ou demonstrativos. Pode-se afirmar, a partir disso, que a teologia é em primeiro lugar poética, isto é, louvor admirado na contemplação da presença do Mistério no mundo.

A atenção à relação entre a teologia e a literatura, que vem se desenvolvendo como um campo de estudo, faz ver a contribuição da literatura para o resgate da dimensão poética da revelação, que foi obscurecida pela autocompreensão da teologia como ciência objetiva proposta pela neoescolástica em reação ao desafio do racionalismo moderno, hoje em fase de superação pela identificação da teologia como ciência hermenêutica ${ }^{3}$. O debate contemporâneo sobre o método situa a teologia no campo das ciências hermenêuticas, já que ela trabalha com textos, mas também porque interpreta a realidade, a presença do Mistério no texto concreto da história viva. Essa perspectiva epistemológica favorece o acolhimento da literatura como mediação para a reflexão teológica.

Essa trajetória da teologia fundamental foi muito bem sintetizada por Geffré (1969). 
Kuschel, grande sistematizador da relação entre teologia e literatura, vai concluir sua obra Os escritores e as escrituras: retratos teológico-literários refletindo sobre a colaboração entre teologia e literatura na apreensão da realidade em sua densidade, a poesia como interlocutora na tarefa de enunciar a irredutibilidade de Deus. Escutando grandes escritores do século XX, afirma que, depois da crise da secularização e da crítica empreendida a uma literatura edificante banal, expressão de piedade leviana e com tom de propaganda religiosa, o discurso sobre transcendência e sobre um Deus transcendente se faz presente na literatura. Demonstra, ao ouvir Kafka, Rilke, Herman Hesse e Thomas Mann, que o discurso sobre Deus nesses autores é fragmentado e filtrado por críticas, mas não refutado. Persiste neles "o esforço por alcançar uma forma de afirmação da realidade transcendente que as restrições feitas por uma crítica clássica à religião não puderam simplesmente eliminar" (KUSCHEL, 1991, p. 212).

Esse autor propõe como modo de aproximação entre teologia e literatura o método da analogia estrutural, que tem como objetivo constatar correspondências e diferenças de maneira dialética, para chegar ao diálogo. O método pede, primeiramente, o distanciamento crítico para evitar a identificação ingênua do discurso literário com a revelação divina e depois a idealização e a aceitação tensionada pela crítica da literatura como lugar de revelação. Num terceiro momento de superação, se procura estabelecer o diálogo sério com a literatura que preserve a autonomia entre os campos, de forma que se chegue a uma correspondência sem que a teologia perca sua referência à revelação divina, nem a literatura perca sua característica de discurso humano situado no tempo e no espaço, e por isso, sujeito a condicionamentos históricos.

A teopoética, enquanto reflexão teológica sobre a realidade em diálogo com a literatura e respeitando sua autonomia, conta com a grande contribuição da poesia enquanto discurso que, para além de toda representação pálida, logra ingressar a fundo na realidade, prestando assim sua colaboração à desbanalização da vida” (KUSCHEL, 1991, p. 210). A reflexão teológica que se faz em diálogo com a literatura supõe o exercício interdisciplinar; deve contar, portanto com a crítica literária.

Como afirma Cantarela, essa aproximação entre religião e literatura é compreensível na medida em que se pressupõe "que o universo particular das tradições religiosas e das espiritualidades não se estabelece fora da linguagem; e que o fenômeno religioso pode ser mais bem compreendido 
quando situado no conjunto de outras manifestações culturais, incluindo as expressões do mundo da arte" (CANTARELA, 2014, p.1229). No que diz respeito mais especificamente à relação entre mística e literatura, pode-se afirmar em concordância com o teólogo Antonio Manzatto, que a linguagem poética "livre e paradoxal, pode melhor servir para expressar a relação com o mistério, e nesse sentido pode ser extremamente interessante para a experiência mística" (MANZATTO, 2011, p.84).

Alex Villas Boas, em um denso artigo sobre a relação entre teologia e literatura, no qual faz a crítica da perda da lógica poética da Revelação, propõe o que chama de teopatodicea. Categoria construída em diálogo com a logoterapia de Victor Frankl, que tem como objetivo apontar o lugar do pensamento poético no discurso sobre Deus, isto é, numa teodiceia que seja resposta à busca humana pelo sentido da vida. A poesia, ele afirma, não é apenas forma de dizer, mas é forma de pensar. O pensamento poético é "forma de manifestação crítica da beleza da existência na busca por um sentido verdadeiro" (VILLAS BOAS, 2016, p.66). Tendo como interlocutor Karl Rahner, propõe que se entenda Deus como

participante de uma teopatodicea, como uma presença misteriosa e desconhecida que se faz perceber como força de sentido quando o sentido se esvai, como que atuando em causas segundas que insistem com o humano (RAHNER, 1984: 93-96). Nesse aspecto, na medida em que o pensamento poético é essencial para a patodiceia, se pensa aqui em um pensamento poético teológico, no qual o sentido de Deus seja reafirmação do humano, ressignificadas as tradições para a tarefa de humanizar o humano. (VILLAS BOAS, 2016, p.78)

Neste artigo, buscamos, a partir da teologia, colocarmo-nos à escuta de Sophia de Mello Breyner Andresen, com o objetivo de explicitar em seus poemas a relação entre mística e poesia, entendendo que a tarefa do teólogo, ou da teóloga, seguindo a reflexão de Rahner, é situar-se diante da poesia sem reduzi-la a uma lição de catequese, mas chamar atenção ao que nela aponta para um dizer da relação com Deus que se revela na criação sem deixar de ser Mistério Santo. A proposta é apontar os elementos místicos presentes na poesia, tendo também como referências na teologia J. Moltmann, E. Schillebeeckx e J. B. Metz. Mais especificamente sobre o fenômeno místico e suas características essenciais, recorremos à análise fenomenológica de Juan Martin Velasco e à abordagem histórica de Bernard McGinn. 
Existem muitos trabalhos que abordam a dimensão da transcendência na obra da poeta a quem dedicamos este artigo, entretanto, no Brasil, nos periódicos da área Ciências da Religião e Teologia, apenas um artigo sobre a poeta foi encontrado. O artigo é de autoria de Luis Adriano Carlos, professor da Faculdade de Letras da Faculdade do Porto, e foi publicado na Revista Teoliterária em 2019, ano em que se comemorou o centenário da poeta

Neste artigo, que não pretende aprofundar os aspectos literários mais técnicos da obra da poeta, elegemos o estudo realizado por Carlos Ceia. Nossa perspectiva se coaduna com a abordagem desse crítico quando afirma que os poemas de Sophia não primam pelas elaborações intelectuais ou pelos conceitos mataforizados, mas expressam a maneira particular de Sophia ver as coisas do mundo, a qual implica simplesmente o relato de impressões: "Na poesia de Sophia, vejo apenas aquilo que é imediatamente apreensível das coisas: a forma, a espécie, a natureza, a essência, mas não objetos do pensamento, enquanto pensados" (CEIA, 2018, posição 661). Afirmação que leva em consideração as palavras da poeta, quando instigada pela crítica que apontava imperfeições formais em seus poemas:

A poesia nunca me interessou "literariamente". A poesia é para mim uma forma de vida. Na poesia eu quis realizar-me[,] salvar-me. No dia em que essa esperança se quebrou eu fiquei vazia e a poesia pareceu-me uma mentira. Por isso a perfeição formal e literária dum poema é para mim uma coisa secundária (ANDRESEN, 1959 apud CEIA, 2018, posição 638)4.

Importante observar também, que não buscaremos trabalhar a partir de uma sistematização da obra de Sophia, mas da escuta de poemas retirados de várias obras, entendendo que existem neles uma constância, uma variação em torno de alguns mesmos temas e um modo de dizer próprio que aparece desde as primeiras obras. Existe na poesia dessa poeta, avalia Ceia (2018, posição 525), "uma rotina de temas que tocam aspectos soltos da cultura clássica greco-romana, raramente recriados com originalidade, dos temas disfarçadamente filosóficos tratados com alguma ligeireza (o ser, o eterno retorno, o tempo, a justiça) e dos temas sobre a primordialidade dos elementos da natureza". ${ }^{5}$

Anotação escrita a lápis encontrada numa cópia da Revista do Livro (Rio de Janeiro, 1959) Este artigo, fruto de projeto de pesquisa desenvolvido no PPG em Ciências da Religião da PUC Campinas, traz elementos de dois trabalhos apresentados em eventos científicos. Um, intitulado Contemplação poética e espiritualidade do cuidado: aproximação teopoética à poesia 


\section{Mística e contemplação poética do mundo: despojamento e busca da unidade}

Sophia de Mello Breyner Andresen nasceu no Porto em 1919 e estudou Filologia clássica na Faculdade de Letras de Lisboa. Casada, fixou-se em Lisboa e passou a dividir o tempo entre a poesia e o ativismo político contra a ditadura de Salazar. Recebeu muitos prêmios, entre os quais se destacam o Prêmio Camões (1999), considerado a maior distinção para um escritor de Língua Portuguesa, e o Prêmio Rainha Sofia de Poesia Iberoamericana (2003), atribuído pelo Patrimônio Nacional da Espanha e pela Universidade de Salamanca. Publicou, em seus 84 anos de vida, mais de vinte livros de poesia, além de livros infantis, ensaios, contos e traduções. Faleceu em 2004. Muito conhecida em Portugal e no âmbito dos estudos literários no Brasil, é pouco estudada no campo das Ciências da Religião e da Teologia.

De ascendência nobre, uma vez que pertencente à elite do Porto, teve, entretanto, momentos de muita dificuldade financeira, a ponto de ter que confiar os filhos aos cuidados de parentes por não ter como prover suas necessidades (NERY, 2019, p. 89). Era uma mulher de elite, mas amava a simplicidade das coisas e das palavras que dão nomes às coisas. Tinha um gosto pela cultura do povo, conforme atesta sua intervenção no programa “Teleforum" transmitido pela RTP em 17 de julho de 1975:

Tudo começa por aquilo que se entende realmente como cultura. Para mim só é cultura a cultura da inteireza, a que implica não só o que um homem sabe, mas a sua maneira de ser, de viver e de estar com os outros. Nesse sentido, considero que o povo português é muito mais culto que os intelectuais de Lisboa. E quando nós chegamos a uma aldeia e vemos fealdade, normalmente foi levada pela cidade. Essa cultura ficou parada e ruída pela pobreza. É preciso dar-lhes condições para que os homens não vivam miseravelmente, que tenham estradas, que tenham água, que tenham médico (NERY, 2019, p. 113).

Sophia, testemunha sua filha Maria Andresen, busca uma poesia despojada. As casas por onde passou e que marcaram sua vida, especialmente a casa de sua infância na Praia da Granja e a casa na Praia da Dona Ana no Algarve, tinham em comum a simplicidade e a proximidade com o mar:

de Sophia de Mello Breyner Andresen, está publicado nos Anais III Colóquio INTERFACES: Esses corpos que me habitam no sagrado do existir, realizado nos dias 08 e 09 de agosto de 2019, em Belo Horizonte, na Faculdade Jesuíta (FAJE); e o outro, intitulado Admiração poética, mistica e crítica social na poesia de Sophia de Mello Breyner Andresen, está publicado nos Anais do VII Congresso da ANPTECRE, realizado nos dias 17 a 20 de setembro de 2019 no Rio de Janeiro, na Pontifícia Universidade Católica do Rio de Janeiro. 
ambas estariam para sempre ligadas a uma sede de frugalidade que na poesia se expressa por uma depuração cada vez mais vasta e obstinada, como se tudo o que fosse luxo se destinasse a destruir o que de essencial existe no esplendor do mundo, como se os excessos em poesia a afastassem de algo de vital que nela procurava (ANDRESEN, 2015, p. 21).

Sua sede de frugalidade está refletida em uma espécie de poema inédito encontrado entre seus papéis: "Dai-me a casa vazia e simples onde a luz é preciosa. Dai-me a beleza intensa e nua do que é frugal. [...] Dai-me a claridade daquilo que é exatamente necessário. Que a vida seja limpa de todo o luxo e de todo lixo." (ANDRESEN, 2015, p. 22). Esse entendimento da simplicidade como qualidade poética essencial vai levar à busca de uma poesia limpa de confessionalismo e liberta da ostentação de um eu carregado de discurso interior, a uma poesia voltada para fora, para o concreto da vida (ANDRESEN, 2015, p. 30). Uma poesia de viés místico, marcada por despojamento e experiência do Mistério por meio do exercício da contemplação.

Mística, define McGinn (2019, p. 49), constitui-se numa "consciência especial da presença de Deus, que por definição excede a descrição e resulta numa transformação da pessoa que a recebe”. O elemento místico no cristianismo "está centrado numa forma de encontro imediato com Deus cujo objetivo essencial é transmitir um conhecimento amoroso (mesmo negativo) que transforma a mente do místico e todo o modo de vida" (p. 50). Paradigmática para a compreensão da mística cristã é a obra Teologia Mística de Dionísio Areopagita. Segundo esse escritor monástico que viveu por volta de 500 d.C., a sabedoria de Deus implica uma dialética ascendente que envolve afirmações e negações que, para ele, “devem ser louvadas com procedimentos contrários” (PSEUDO-DIONÍSIO, O AREOPAGITA, 2005, p. 21).

Dionísio indica que a relação com Deus absolutamente transcendente implica o êxtase operado por meio do procedimento da negação (remoção), com a finalidade última da união transformadora (divinização) pelo amor que é Deus, em absoluto transcendente e presente em toda a criação. Mística é, para ele, qualidade da teologia, um tipo de sabedoria de Deus na qual penetram os iniciados que se dispõem a despojarem-se do próprio saber e, abandonando-se de forma irrestrita, absoluta e pura, deixam-se conduzir para o alto e viver naquele que a tudo transcende, unindo-se ao princípio superdesconhecido segundo o melhor de suas faculdades, mas conhecido 
além da inteligência (PSEUDO-DIONÍSIO, O AREOPAGITA, 2005, p. 18). O que a tradição cristã aprende de Dionísio é que todo conceito positivo sobre Deus, todos os gestos propostos, todas as leis, todos os ritos, todas as imagens, devem ser considerados em sua função de sustentação no caminho para Deus, mas, ao mesmo tempo, que tudo isso acaba sendo relativizado na medida da aproximação com o Deus vivo absolutamente transcendente. Daí se infere que mística é uma forma intensiva da fé apoiada numa dialética que articula despojamento e experiência de Deus como Mistério Santo, inefável, impossível de ser contido nos limites da razão.

Também podemos interpretar como despojamento o fato de não ser a obra poética de Sophia centrada em sua biografia. Segundo Ceia (2018), a poeta esquiva-se de oferecer dados da sua vida pessoal, não tem um discurso confessionista. Sua breve biografia, por ela mesma, é dita a partir de sua relação com o real em sua concretude natural:

Tive amigos que morriam, outros que partiam

Outros quebravam o seu rosto contra o tempo.

Odiei o que era fácil

Procurei-me na luz no ar e no vento.

(ANDRESEN, 2015, p. 392).

Aspira ser "uma cidadã espiritual de um mundo onde seja possível embrenhar-se de forma a extrair a positividade necessária para fazer dela a própria identidade" (CEIA, 2018, posição 145). O mundo é sua biografia. Sua identidade se constrói, tudo nela se acrescenta pela contemplação do real concreto em sua elementaridade natural:

Por isso não me peça, cartão de identidade

Pois nenhum outro senão o mundo tenho

Não me peçam opiniões nem entrevistas

Não me perguntem datas nem moradas

De tudo quanto vejo me acrescento.

(ANDRESEN, 2015, apud CEIA, 2018, posição 146).

A experiência das coisas em si mesmas, desprovida de subjetividade e dada como função primordial da vida, verbaliza-se em sua poesia. "A obra de Sophia é um exercício de simplicidade sobre as coisas concretas" (CEIA, 2018, posição 227). A poeta rejeita as experiências individuais do tipo confessional e a transposição da sua vida pessoal para a poesia. Evita 
falar em primeira pessoa. Busca concentrar-se na contemplação da noite, do jardim, da praia, do mar, das flores, da casa, da fonte, da rua, da cidade etc. Uma poesia isenta de biografismo denota, podemos afirmar, certo despojamento de si. Uma experiência paradoxal da subjetividade que implica o êxodo de si - como condição de abertura para o encontro com a totalidade - é apontado pelos estudiosos como característica de um discurso místico. Em várias narrativas consideradas místicas podemos perceber um itinerário que inclui esvaziamento. A mística medieval renana chega a usar o termo "aniquilamento", e místicos modernos (por exemplo, Santo Inácio) vão falar de "indiferença" para se referir ao itinerário trabalhoso de abandono de apegos para a aquisição de maior liberdade e abertura ao divino absolutamente transcendente, que é, nas palavras de Dionísio Areopagita (2005, p. 15), "[a treva] superesplendente na mais profunda obscuridade que é, supermanifesta e superclaríssima”. O descentramento de si é um entre os elementos essenciais do fenômeno místico.

Velasco, em sua análise fenomenológica, aponta os seguintes elementos como essenciais na caracterização do fenômeno místico: (1) é uma experiência subjetiva que afeta o humano como um todo e tem lugar no centro da pessoa; (2) é vivido de forma insuperavelmente obscura e sumamente certa; (3) é uma experiência passiva, recebida como dom; (3) tem caráter extático, supõe descentramento; (4) impõe uma forma específica de uso das faculdades: a razão não atua explicando, compreendendo, mas escutando, e a vontade não intervém dominando, mas fazendo-se disponível e acolhendo; (5) impõe, nesse sentido, uma nova forma de ser que não se opera com base em possuir ou dominar, mas na disposição para entregar-se e acolher; é uma experiência que tem caráter oblativo (VELASCO, 1994, p. 79).

A mística como forma de experiência religiosa indica a necessidade de empreender um caminho crítico para se chegar ao núcleo da experiência. Em termos fenomenológicos, pode-se dizer que a meta do itinerário místico é a união com o Mistério Santo. Esse itinerário, segundo a tradição mística, supõe o atravessamento e ultrapassamento de todas as mediações numa dialética que implica a negação metódica de tudo o que se procura afirmar acerca da relação com Deus. O místico é aquele que intui por experiência a existência de uma Presença que ultrapassa tudo o que é possível pensar e desejar; Presença com a qual, no entanto, é possível se relacionar. As narrativas místicas descrevem esse itinerário como um caminho de despojamento que resulta, por outro lado, no encontro com o absoluto em seu mistério inefável. (VELASCO, 1994, p. 79). 


\section{Da busca de integridade ao encontro com o Mistério}

Outro elemento que caracteriza o viés místico da obra poética de Sophia, ao nosso ver, é a referência a Deus como mistério. Percebemos essa consciência da presença do mistério inefável na obra da poeta como fruto de sua atitude contemplativa diante do mundo, a qual se direciona, sobretudo, para a natureza em seus elementos essenciais, destacando-se a relação com o mar.

Contemplar é conhecer com os olhos. Os filósofos gregos, os Padres da Igreja e os pais do monaquismo, lembra J. Moltmann (1999), "compreendiam as coisas pelos olhos":

Atingimos a compreensão do real quando contemplamos uma flor ou um pôr-do-sol ou uma manifestação de Deus até que esta flor passe a ser a flor como tal, e este pôr-do-sol o por do sol como tal, e esta manifestação de Deus total e inteiramente o próprio Deus. Então aquele que contempla passa a ser ele mesmo uma parte da flor, do por do sol ou de Deus. Pois através do seu conhecer ele participa de seu objeto de conhecimento e é transportado para ele. O conhecer modifica quem conhece, não aquilo que é conhecido. O conhecimento cria comunhão. A gente conhece para participar, não para dominar (p. 191; grifo do autor).

Meditação e contemplação são, para esse teólogo, dois momentos do conhecimento do real por participação. A meditação é o momento do mergulho no objeto. Meditar é deixar-se absorver, esquecer-se de si, perderse no objeto para o qual se está orientado. A contemplação é o retorno à própria percepção. Se na meditação percebe-se o objeto, na contemplação percebe-se a própria percepção e as transformações que a meditação opera em si. Meditação e contemplação, entendidas conjuntamente, devem levar ao conhecimento objetivo da coisa em si, daquilo que na realidade se dá a conhecer, conhecimento da realidade em si mesma: "a flor como tal", "o pôrdo-sol como tal", e "Deus total e inteiramente o próprio Deus". Conhecer nesse sentido é, portanto, "um sofrer impressões e tem como base uma receptividade daquele que conhece” (MOLTMANN, 1999, p. 195).

Para esse teólogo, a meditação e a contemplação têm ligação com a mística, na medida em que implicam um caminho direto para conhecer a Deus, o qual supõe um processo que inclui entrega e recepção. Um conhecimento direto, entretanto, em que o revelado que se manifesta permanece velado em seu mistério. Esse é, talvez o maior paradoxo daquilo que se denominou experiência mística. As narrativas consideradas místicas 
almejam falar de algo que é indizível, descrever o que não pode ser descrito; afirmam conhecer para além de suas condições de conhecimento.

A história infantil A menina e o mar (2009) conta da admiração de Sophia pelo mar, que tem raízes na infância. É a história de um rapazinho que morava numa casa branca (tal qual a casa de suas lembranças de infância), adorava as rochas, adorava o verde das algas, o cheiro da maresia, a frescura transparente das águas e, um dia, depois de grande tempestade, estando a passear pela praia e brincar entre as rochas, encontrou uma menina de um palmo de altura, a menina do mar, com quem travou uma grande amizade. $\mathrm{O}$ menino apresentou-lhe as belezas da terra - a rosa, uma caixa de fósforos (o fogo) e o vinho - e escutou dela sobre as aventuras do mar. Cresceram em amizade, mas foram obrigados a se separar. A menina entristeceu, aprendeu o que é saudade. Boa dançarina que era, passou a dançar muito mal. Diante da tristeza da menina, o Rei do Mar se empenhou em ajudá-la, e deu a ela recursos para trazer o menino ao seu encontro no mar. Embora seja uma fantasia destinada à infância, esse texto diz muito da própria poeta e sua relação com o oceano, do seu desejo de "unir terra e água numa mesma pátria de alegria e fluidez", comenta Lilian Jacoto na apresentação do livro (ANDRESEN, 2018, posição 272).

No poema "Mar" (ANDRESEN, 2015, p. 65), fala de seu amor ao mar que provoca nela a selvagem inspiração de um grito puro que sobe aos astros. As evocações poéticas de Sophia têm caráter visual, seu olhar pousa sobre a terra, admira a eternidade das paisagens e extasia-se, reverente, com a imensidão do oceano: "Planície infinita que ninguém habita" (ANDRESEN, 2015, p. 95). Na poesia intitulada "Atlântico", ela confessa: "Mar, metade de minha alma é feita de maresia" (ANDRESEN, 2015, p. 64); e, em "Mar sonoro" (ANDRESEN, 2015, p. 65), ela expressa seu fascínio por essa imensidão, que recebe como dom:

Mar sonoro, mar sem fundo, mar sem fim,

A tua beleza aumenta quando estamos sós

E tão fundo intimamente a tua voz

Segue o mais secreto bailar do meu sonho,

Que momentos há em que eu suponho

Seres um milagre criado só para mim.

A poesia da Sophia é de natureza elemental, interpreta Ceia (2018). Vento/ar, luz/fogo, jardim/terra são os elementos com os quais ela trabalha 
em termos simbólicos. Tratados em sua materialidade, sujeitos às leis do tempo e dos espaços, atravessam os habituais ciclos de vida e de morte. Segundo o crítico, esses elementos, na poesia de Sophia, não são harmoniosos entre si: na guerra oculta entre eles, apercebe-se o jogo entre o caos e a ordem e se introduz o mistério da Quintessência (posição 754). Sophia é, nesse contexto, uma poeta caminhante em busca da reconciliação entre os opostos que vivem no caos primitivo. Caminha

sempre de verso em verso, de poema em poema, de praia em praia, de jardim em jardim [...] O simbolismo da viagem será sempre o mesmo: a procura da justiça e da verdade, da paz e da liberdade, da harmonia e da união com as coisas. O que se dirá acerca da navegação, da demanda de ilhas míticas, do desejo de unidade com a natureza, será tudo uma preparação para uma viagem maior de busca do centro espiritual, cujo símbolo máximo é Delphos (CEIA, 2018, posição 714-725).

A Grécia é central na obra da poeta; mais do que um lugar, comenta Nery (2019, p. 140), "passou a ser um estado de espírito". De sua viagem a Delfos, Sophia registra sua impressão, em carta escrita ao amigo Jorge de Sena:

Delfos é o lugar mais espantoso que vi na minha vida, um lugar deslumbrante e solene entre montanhas altíssimas, com fontes geladas, em frente dum vale coberto de arvoredos e bosques e com um pedaço de mar a brilhar entre as encostas. Um lugar onde todos os elementos, luz, som, ar, água, terra tomam uma veemência apaixonada e sagrada (ANDRESEN; SENA, 2010, p. 105).

Para Ceia (2018, posição 1236), a poesia de Sophia pode ser vista como uma navegação onírica em busca de ilhas misteriosas onde se pode encontrar a clareza e a luz primordiais: "busca mítica de unidade que desde os primeiros poemas Sophia tem vindo a descrever [...]. A unidade não é só a perfeição das coisas, mas também o sonho de encontrar um país sem mal". Sonho que ela alimenta sem ilusão. Com ironia bem-humorada própria da maturidade de quem teve uma atuação marcante na vida política, num poema do livro As ilhas, de 1989, compara os índios errantes, exaustos, exauridos aos revolucionários do seu tempo:

Um etnólogo diz ter encontrado

Entre selvas e rios depois de longa busca

Uma tribo de índios errantes

Exaustos exauridos semimortos 
Pois tinham perdido desde há longos anos

Percorrendo florestas desertos e campinas

Subindo e descendo montanhas e colinas

Atravessando rios

Em busca do país sem mal -

Como os revolucionários do meu tempo

Nada tinham encontrado.

(ANDRESEN, 2015, p. 802).

A busca de unidade que se percebe nos poemas, é importante ressaltar, não se identifica com uma filosofia do absoluto, pois, como aponta Silvina Rodrigues Lopes (1990, apud CEIA, 2018, posição 1270), nota-se nos poemas uma poética da experiência dos olhos abertos para a diversidade, profusão, estranheza de onde se retira a forma simples e perfeita que é o poema. A busca de unidade, ou da revelação do absoluto, da verdade, implica o acolhimento do real em sua multiplicidade, a qual espanta e provoca deslumbramento. Sobre a inspiração para o livro Navegações, publicado em 1983, depois de viagem ao Oriente, Sophia escreve:

À medida que os poemas iam surgindo ia-se decidindo em mim a vontade de os editar ao lado dos mapas de época, os mapas onde ainda é visível o espanto do olhar inicial, o deslumbramento perante a diferença, perante a multiplicidade do real, a veemência do real mais belo que o imaginado, o maravilhamento perante os coqueiros, os elefantes, as ilhas, os telhados arqueados dos pagodes. E também a revelação de um outro rosto do humano e do sagrado.

$[\ldots]$

Para mim o tema da Navegações não é apenas o feito, a gesta, mas fundamentalmente o olhar, aquilo a que os gregos chamavam aletheia, a desocultação, o descobrimento. Aquele olhar que às vezes está pintado à proa dos barcos (ANDRESEN, 2015, p. 751-752).

Vemos, com isso, seu desejo de ir ao essencial na contemplação do concreto, captando a presença misteriosa de uma realidade absoluta com quem é possível se relacionar. No livro Dia do mar, de 1947, encontramos poemas que podem ser lidos, sob o prisma da teologia da revelação, como uma prece reveladora dessa atitude:

Dei-te a solidão do dia inteiro.

Na praia deserta, brincando com a areia, 
No silêncio que apenas quebrava a maré cheia

A gritar o seu eterno insulto,

Longamente esperei que o teu vulto

Rompesse o nevoeiro.

Esgotei o meu mal, agora

Queria tudo esquecer, tudo abandonar,

Caminhar pela noite afora

Num barco em pleno mar.

Mergulhar as mãos nas ondas escuras

Até que elas fossem essas mãos

Solitárias e puras

Que eu sonhei ter.

(ANDRESEN, 2015, p. 130-131).

Vislumbra-se, aqui, a entrega em solidão ao silêncio, à espera de uma presença reconciliadora que acolha o mal e transforme o agir, tornando as mãos solitárias e puras. Solidão, silêncio, deserto, abandono, pureza são elementos que aparecem em várias narrativas consideradas místicas.

A poesia de Sophia nasce da contemplação do mundo, do mar, do jardim, do luar. Ela ama a solidão da noite no jardim, sua sombra e seu silêncio, sua harmonia perfeita:

Atravessei o jardim solitário e sem lua,

Correndo ao vento pelos caminhos fora, para tentar como outrora

Unir a minha vida à tua,

Ó grande noite solitária e sonhadora.

[...]

Docemente a sonhar entre a folhagem

A noite solitária e pura

Continuou distante e inatingível

Sem me deixar penetrar no seu segredo.

Eu senti quebrar-se, cair desfeita,

A minha ânsia carregada de impossível,

Contra a sua harmonia perfeita.

(ANDRESEN, 2015, p. 67-68).

Na concretude do real, anuncia em versos o Mistério inominável, "perfeição, pureza e harmonia" presentes na profundidade do mundo: 


\section{Contemplação poética e mistica em Sophia de Mello Breyner Andresen}

Ir beber-te num navio de altos mastros

No mar alto

Ó grande noite alucinada e pura

Brilhante e escura, bordada de astros.

Para ti sobe a minha inquietação e sobressalto,

O meu caos, desilusão e agonia,

Pois trazes nos teus dedos

A sombra, o silêncio e os segredos,

A perfeição, a pureza e a harmonia.

(ANDRESEN, 2015, p. 77).

Do assombro e veneração em face do universo, deriva uma forma de falar de Deus como mistério cujo nome não pode ser manipulado, que está em tudo e não está em nada, apenas intuído no olhar daqueles que Ele escolheu. O poema "Sinal de Ti" é um belo exemplo:

A presença dos céus não é a Tua, Embora o vento venha não sei donde.

Os oceanos não dizem que os criaste, Nem deixas o Teu rasto nos caminhos.

Só o olhar daqueles que escolheste

Nos dá o Teu sinal entre os fantasmas.

(ANDRESEN, 2015, p. 116-117).

Nesse poema, vemos os sinais de panenteísmo, a percepção da presença do Mistério Santo em todas as coisas, mas sem se confundir com elas. Presença oferecida ao olhar dos escolhidos para anunciá-la, mas que permanece velada aguardando o consentimento livre para o acolhimento da revelação. $\mathrm{Na}$ tradição mística cristã, afirma Moltmann, mesmo marcada pelo idealismo neoplatônico e pelo dualismo gnóstico, encontra-se o testemunho da visão panenteísta do mundo em Deus e de Deus no mundo, que tem como referência a doutrina da criação. Ele cita como exemplo as palavras de Mestre Eckhart (1977, apud MOLTMANN, 1998, p. 202): “Quem tem Deus assim (isto é) no ser, este recebe Deus divinamente e para este ele resplandece em todas as coisas; pois todas as coisas lhe sabem a Deus e a imagem de Deus se torna visível em todas as coisas". Em estilo de oração, vemos também a poeta expressar, no poema a seguir, essa sua consciência da presença do "Senhor" no mundo, percepção que ela quis adiar (ou não quis explicitar) para poder ver o mundo em si:

Senhor sempre te adiei 
Embora sempre soubesse que me via Quis ver o mundo em si e não em ti E embora nunca te negasse te apartei. (ANDRESEN, 2015, p. 805).

Enfim, na escuta dos poemas de Sophia, tomando cuidado de não fazer uma identificação ingênua entre o discurso literário e a teologia da revelação, como recomenda Kuschel, podemos reconhecer a presença de elementos místicos, especialmente relacionados com o estilo despojado (gosto pela simplicidade) e a experiência de Deus como Místério Santo na contemplação da natureza; ainda, como desdobramento, podemos apontar o anseio de justiça, a crítica da sociedade e o compromisso político.

\section{Das fontes ao anseio de justiça: a poesia como crítica da sociedade e compromisso político}

J. Moltmann, olhando para a tradição espiritual cristã, critica o que chama de "espiritualidade da alma", vivência que se desenvolveu como fruto do encontro com a tradição platônica, na qual se enfatizou o dualismo grego e o gnosticismo, e que trouxe como consequência uma espiritualização da redenção. O messianismo é substituído pelo anseio do além, e o Espírito não é mais compreendido como fonte de vida, mas como redentor da alma do cativeiro do corpo. "A consequência é", afirma o teólogo, "que uma 'espiritualidade' dócil, desvinculada dos sentidos, hostil ao corpo, separada do mundo, e sem a menor dimensão política, assumiu o lugar da vitalidade original, judaica e cristã, que vive a partir do Espírito Criador de Deus" (MOLTMANN, 2002, p. 82). Sem conseguir entrar, aqui, nos detalhes dessa relação tensa com o mundo promovida pela experiência mística, podemos afirmar que a esta tem uma dimensão crítica.

Na definição do teólogo E. Schillebeeckx (1994, p. 98-99), mística é uma forma intensiva de experiência de Deus na fé, vinculada à sua dimensão cognitiva. Considerando os dois aspectos dessa dimensão - um que diz respeito às representações, conceitos e imagens, e outro que se relaciona com o contato cognitivo com a realidade de Deus -, a mística pode ser definida, mais especificamente, como uma forma intensiva deste elemento cognitivo que nos une com Deus na fé e põe em crise as representações humanas do divino. Esse é o grande paradoxo da mística: o esfacelamento das representações e das mediações constituídas no seio de sistemas religiosos que ela provoca. 
Nesse sentido, pode-se dizer que, apoiada na convicção da absoluta transcendência de Deus, a mística é crítica: faz ver o limite da condição humana e a impossibilidade que ela tem de abarcar o mistério inconcebível e "indisponível” que é Deus; faz ver com maior clareza a relatividade de todos os esforços humanos instituídos como mediações nesse caminho em busca do Transcendente.

Mesmo afirmando a relatividade que marca nossa vivência humana neste mundo, diferentemente do que muitas vezes se pensa, a experiência mística não leva necessariamente ao desprezo da realidade mundana - ao contrário, muitas vezes conduz a um forte compromisso com a transformação social.

Se a divinização descrita em termos místicos supõe desprendimento do mundo, desapego e até aniquilamento de si, o encontro com o Mistério Santo - o "de onde" e o "para onde" de todas as coisas - possibilita um novo olhar para a realidade, cuja dimensão política, a consciência histórica moderna, ajuda a explicitar. A "mística de olhos abertos” de Metz (2013), que se encontra em muitos testemunhos místicos contemporâneos, tem no centro a compaixão, que é, para o teólogo, percepção participativa do sofrimento alheio que suscita mudança de visão e também disposição para olhar e avaliar a vida através dos olhos dos sofredores e ameaçados. Essa mudança de visão, por sua vez, provoca o descentramento: ao deixar-se interromper pelos sofrimentos dos outros, tem-se os desejos, interesses e preferências relativizados.

Para Metz, uma revolução antropológica se opera por essa interrupção. Uma força de oposição, que ele define como espírito pentecostal, capacita para a interrupção dos contextos terrenos de violência. É a graça de Deus que ensina "aos corações a arte de parar e dar meia volta, quando o 'Adão' natural tenta sempre prosseguir". Espírito e graça expressam-se como força de oposição quando a opressão geral das reproduções sociais exige que tudo continue da maneira como está (METZ, 2013, p. 139).

Nesse contexto, de volta à poeta, é importante frisar que a atenção de Sophia à natureza não a retira das preocupações com a vida social. Os mesmos olhos que pousam sobre o mar e percorrem o jardim encontrando “perfeição, pureza e harmonia" (ANDRESEN, 2015, p. 77) enxergam compadecidos a convivência humana e sonham como um mundo justo. No poema "As fontes", encontramos esse movimento de ascese poética amorosa, que, sem desprezar a vida no mundo, num exercício de desprendimento, coloca em seu horizonte a plenitude como meta e busca o cumprimento de 
si no encontro com a Fonte que é o Real, horizonte vislumbrado "em cada hora e na face incompleta do amor":

Um dia quebrarei todas as pontes

Que ligam todo o meu ser, vivo e total,

À agitação do mundo irreal,

E calma subirei às fontes.

Irei até as fontes onde mora

A plenitude, o límpido esplendor

Que me foi prometido em casa hora,

E na face incompleta do amor.

Irei beber a luz e o amanhecer

Irei beber a voz dessa promessa

Que às vezes como um voo me atravessa,

E nela cumprirei todo o meu ser.

(ANDRESEN, 2015, p. 106).

Discorrendo sobre a beleza na poesia de Sophia, L. A. Carlos (2019) aponta a dualidade presente na obra, o "drama da beleza". O esplendor que ela busca, afirma ele, não é apenas metafísico, mas também fenomênico: "A perfeição das Formas participa de um jogo de dualidades em que o imperfeito e o Kaos disputam preponderância" (p. 342). O esplendor do mundo é luz que não ofusca o seu sofrimento; a demanda de beleza desce ao múltiplo, à alteridade da matéria, e enfrenta o trágico e o feio.

No livro O nome das coisas (1977), que reúne poemas situados entre 1972 e 1976, momento de grande agitação política em Portugal, destacamos a poesia intitulada "Forma justa". Nela, suscitada certamente pelo envolvimento com a Revolução dos Cravos (1974), a poeta afirma a utopia de um mundo justo, inspirado na contemplação da harmonia do universo. Sonha com a cidade humana construída segundo a "forma justa", "fiel à perfeição do universo", e reafirma a sua contribuição de poeta na reconstrução do mundo:

Sei que seria possível construir o mundo justo

As cidades poderiam ser claras e lavadas

Pelo canto dos espaços e das fontes

O céu o mar e a terra estão prontos

A saciar a nossa fome do terrestre

A terra onde estamos — se ninguém atraiçoasse — proporia 
Cada dia a cada um a liberdade e o reino

- Na concha na flor no homem e no fruto

Se nada adoecer a própria forma é justa

E no todo se integra como palavra em verso

Sei que seria possível construir a forma justa

De uma cidade humana que fosse

Fiel à perfeição do universo.

Por isso recomeço sem cessar a partir da página em branco E este é meu ofício de poeta para a reconstrução do mundo.

(ANDRESEN, 2015, 710).

Sophia entendia a poesia como busca de uma unidade primordial com a natureza, busca que inclui a relação com as pessoas e deve ser fundada na liberdade. Ela tem em mente um projeto de inteireza. A contemplação poética da natureza implica, portanto, para ela, a busca pela justiça.

Mulher de sensibilidade política, teve participação ativa na oposição ao Estado Novo. Foi candidata pela oposição democrática nas eleições legislativas de 1968 e sócia fundadora da Comissão Nacional de Socorro aos Presos Políticos. Após a revolução de abril de 1974, foi candidata à Assembleia Constituinte pelo Partido Socialista em 1975.

O extrato a seguir da poeta portuguesa, lido no I Congresso de Escritores Portugueses em 10 de maio de 1975, um ano após a conhecida Revolução dos Cravos, e publicado no livro O nome das coisas, de 1977, expressa muito bem a relação entre contemplação poética, mística e crítica social em sua obra.

Pois a poesia busca o verdadeiro estar do homem na terra e não pode por isso alheiar-se dessa forma do estar na terra que a política é. Assim como busca a relação verdadeira do homem com a árvore ou com o rio, o poeta busca a relação verdadeira com os outros homens. Isso o obriga a buscar o que é justo, isto o implica naquela busca de justiça que a política é (ANDRESEN, 1977, p. 77).

Ela acreditava que a arte poética era fundamentalmente crítica; que a poesia desaliena, que é por natureza desalienação primordial, visto que "estabelece a relação inteira do homem consigo próprio, com os outros, e com a vida, com o mundo e com as coisas" (ANDRESEN, 1977, p. 78). Critica o uso burguês da cultura, que separa o cérebro das mãos, o trabalhador 
intelectual do manual, enfim, "o homem de si próprio, dos outros e da vida" (Ibidem, p. 78). Entende que só uma relação primordial limpa, justa e que possibilite o acesso à verdade das coisas promove uma revolução real. A política deve, portanto, servir ao projeto de inteireza da poesia. Sua tarefa seria a de criar condições em que a desalienação seja possível. A poesia é, para ela, revolucionária, e o escritor deve participar dessa revolução.

O artista não é um homem isolado - afirma ela em texto publicado com o título "Arte poética III" (ANDRESEN, 2015, p. 893-894), proferido por ocasião da entrega do Grande Prêmio de Poesia a Livro Sexto em 1964 -; mesmo aquele que se coloca à margem da convivência, exerce influência através de suas obras. Embora fale apenas sobre pedras e brisas, a obra de arte quer sempre dizer-nos que não somos animais acossados na luta pela sobrevivência, mas herdeiros da liberdade e dignidade do ser. Para Sophia, a busca da justiça é uma coordenada fundamental de toda a obra poética:

Quem procura uma relação justa com a pedra, com a árvore, com o rio, é necessariamente levado, pelo espírito de verdade que o anima, a procurar uma relação justa com o homem. Aquele que vê o espantoso esplendor do mundo é logicamente levado a ver o espantoso sofrimento do mundo (ANDRESEN, 2015, p. 893).

O poeta que admira o esplendor do mundo com paixão, ela afirma, experimenta revolta com o sofrimento do mundo também com paixão. Louvor e protesto, para ela, são sinais de unidade da consciência desalienada pela poesia.

\section{Considerações finais}

Nossa intenção neste artigo, como se pôde ver, não foi colocar a poeta entre os místicos, mas apontar características místicas em seus poemas, que se apresentam a nós como frutos de uma atitude contemplativa diante do mundo, considerando que a escuta da poesia é tarefa importante da teologia num tempo em que o debate epistemológico afirma a centralidade da linguagem.

A experiência mística, testemunham muitas narrativas, é da ordem do inefável, pois opera além do limite da razão e é, portanto, indizível. Entretanto, mesmo reconhecendo a insuficiência da linguagem, observa-se nas narrativas místicas o empenho na busca por uma forma de expressão. Nota-se a convicção de que a experiência não pode ficar encapsulada no sujeito, mas 
deve ser partilhada. Nesse sentido, o uso de expressões paradoxais, metáforas e símbolos, como também a poesia têm servido de recursos de expressão dessa experiência. Segundo Velasco, "essa luta exaustiva dos místicos com as palavras não leva ao naufrágio de sua linguagem. Ao contrário, desperta suas capacidades expressivas e leva ao limite o poder significativo das palavras" (VELASCO, 2004, p. 19).

Como pudemos ver, os olhos abertos de Sophia parecem pousar no mundo em sua materialidade e penetrá-lo, trazendo da profundidade versos que apontam para o Mistério Santo encontrado no fundamento de todas as coisas; para as "fontes" onde mora a plenitude prometida "em cada hora" (ANDRESEN, 2015, p.106) ao longo de nossa vivência no mundo e "na face incompleta do amor" (ANDRESEN, 2015, p.106). O Mistério é vislumbrado após de um procedimento de remoção comparável, segundo Pseudo-Dionísio Areopagita (2005, p. 21), à arte dos que, ao modelar uma bela estátua, "aplainam-lhe os impedimentos que poderiam obnubilar a pura visão de sua arcana beleza, sendo capazes de mostrá-la plenamente, mediante a remoção".

O caminho para as fontes supõe, como pudemos perceber nos poemas destacados, um processo de desprendimento identificado com o desejo de simplicidade: "a casa vazia e simples onde a luz é preciosa" (ANDRESEN, 2015, p. 22). A experiência paradoxal da subjetividade, uma maneira de falar sobre si sem se centrar em si mesmo, mas centrando-se no mundo que se encontra diante dos seus olhos, dá aos poemas um viés místico.

Sendo experiência de conhecimento direto adquirido pela via da contemplação, a mística conta com esse processo de esvaziamento. Nesse contexto, ilustram a maneira de Sophia lidar com a referência a si mesma nos poemas as palavras de Francisco de Sousa Tavares, seu marido e primeiro crítico, citadas por Ceia (2018, posição 591): "Sophia Andresen fala de si [...] com um pudor feito de respeito pelas coisas; ela própria é como o mundo, na estranha agitação que a debate a anima, no sonho de beleza que a seduz".

Vimos, finalmente, que a perfeição, pureza e harmonia que Sophia vislumbra por meio da contemplação do real inspiram o compromisso político. Nesse sentido, é possível associar os poemas a uma "mística de olhos abertos": como pudemos constatar, a contemplação que inspira a poesia não leva a uma fuga do mundo, mas, ao compromisso com a sociedade, para a qual a poeta almeja uma "forma justa". 


\section{Referências}

ANDRESEN, S. de M. B. Obra poética. Porto: Assírio\&Alvim, 2015.

O nome das coisas. Lisboa: Moraes Editores, 1977.

. A menina e o mar. São Paulo: Sesi-SP, 2018. Edição Kindle.

BOFF, C. Teoria do método teológico. Petrópolis: Vozes, 2015.

CARLOS, L. A. O drama da beleza na poesia de Sophia de Mello Breyner Andresen. Teolíterária, São Paulo, v. 9, n. 18, p. 332-354, 2019.

CANTARELA. A pesquisa em teopoética no Brasil: pesquisadores e produção bibliográfica. Horizonte, Belo Horizonte, v. 12, n. 36, p.1228-1250, out./dez. 2014. Disponível em: <http://periodicos.pucminas.br/index.php/horizonte/article/view/P.21755841.2014v12n36p1228/7526>. Acesso em: 24 out. 2017.

CEIA, C. Iniciação aos mistérios da poesia de Sophia de Mello Breyner Andresen. Lisboa: Vega, 2018. Edição Kindle.

GEFFRÉ, C. A história recente da Teologia Fundamental, tentativa de interpretação. Concilium, Navarra, v. 6, p. 7-26, jun. 1969.

KUSCHEL, K. Os escritores e as escrituras: retratos teológico-literários. São Paulo: Loyola, 1999.

MANZATTO, Antonio. Pequeno panorama de teologia e literatura. In: MARIANI, Ceci Baptista; VILHENA, Maria Angela. Teologia e Arte: Expressões de transcendência, caminhos de renovação. São Paulo: Paulinas, 2011, p. 87-98.

MARIANI, C. M. C. B. Contemplação poética e espiritualidade do cuidado: aproximação teopoética à poesia de Sophia de Mello Breyner Andresen. ANNALES FAJE. v. 4, n.3, p. 94-102, 2019. Disponível em: http://faje.edu.br/periodicos/index.php/annales/article/ view/4319/4352. Acesso em: 15/11/2019.

MARIANI, C. M. C. B. Admiração poética, mística e crítica social na poesia de Sophia de Mello Breyner Andresen. In: Anais do VII Congresso da ANPTECRE: Religião e crise socioambiental, 2019, Rio de Janeiro. 2019. p. 622-629.

MCGINN, B. As fundações da mística: das origens ao século V. São Paulo: Paulus, 2012. v. 1. METZ, J. B. Mística de olhos abertos. São Paulo: Paulus, 2013.

MOLTMANN, J. O Espírito da vida: uma pneumatologia integral. Petrópolis: Vozes, 1998.

2002.

. A fonte de vida: O Espírito Santo e a teologia da vida. São Paulo: Loyola,

NERY, I. Sophia de Mello Breyner Andresen. Lisboa: A Esfera dos Livros, 2019.

PSEUDO-DIONíSIO, O AREOPAGITA. Teologia mística. Rio de Janeiro: Fissus, 2005.

RAHNER, K. La palabra poetica y el cristianismo. In: Escritos de teologia IV:

escritos recientes. Madrid: Taurus, 1964. p. 453-466. 
SCHILLEBEECKX, E. História humana, revelação de Deus. São Paulo: Paulus, 1994.

VELASCO, J. M. (Org.). La experiência mística. Madrid: Trotta, 2004.

VILLAS BOAS, A. Recuperar a lógica poética da Revelação. Interações, v. 11, n. 19, p. 61 86, 2 ago. 2016. Disponível em: http://periodicos.pucminas.br/index.php/interacoes/article/ view/P.1983-2478.2016v11n19p61. Acesso em: 18/07/2020.

Submetido em: 29-9-2020

Aceito em: 26-11-2020 